\title{
A Simplified Technique for Orientation of a Bone Anchored Auricular Prostheses: a Clinical Report
}

\author{
Hussein G. El Charkawi', Ahmed G. El Sharkawy² \\ ${ }^{1}$ Faculty of Oral and Dental Medicine, Future University, Cairo, Egypt. \\ ${ }^{2}$ Plastic Surgery, Faculty of Medicine, Cairo University, Egypt.
}

\section{Corresponding Author:}

Hussein El Charkawi

Faculty of Oral and Dental Medicine, Future University

4 El Nabawi El Mohandes St. Agouza, Cairo

Egypt

Phone: 01222150439

Fax: (202) 25171697

E-mail: helcharkawi@gmail.com

\section{ABSTRACT}

Background: A simple technique was presented in this clinical report for orientation of a bone anchored auricular prosthesis. Methods: The proposed technique includes drawing the intact ear on a transparent celluloid paper or radiographic film and flipping it to the opposite side and relating it to the fixed anatomical features on the face of patient.

Results: The drawing, by this way provides a simple and easy way to duplicate and transfer the exact size and position of the intact ear to the defect side.

Conclusions: This technique provides a simple, safe, inexpensive and time saving yet, an accurate and effective surgical template that orients the craniofacial implants to the confines of the definitive auricular prosthesis. It is indicated for restoration of single missing external ear either in aplasia, injuries and total resection.

Keywords: ear deformities, acquired; ear, external; ear cartilage; prostheses and implants; osseointegration; quality of life.

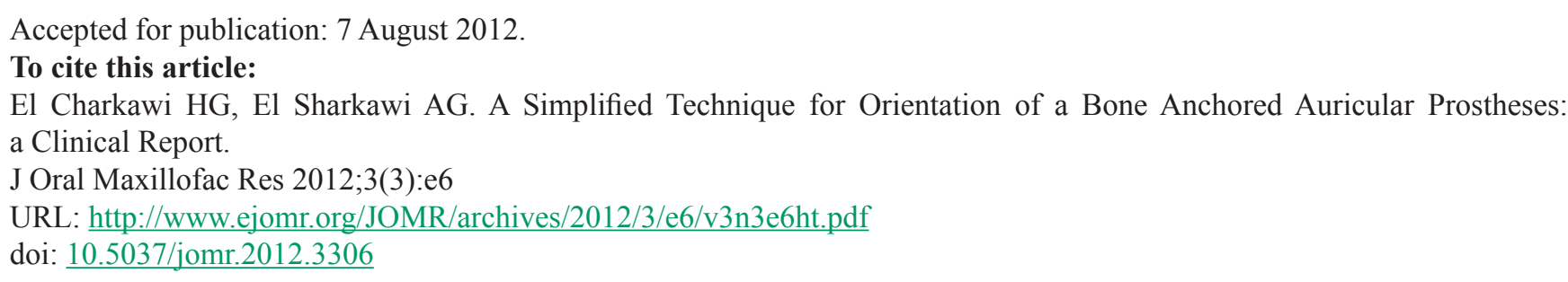




\section{INTRODUCTION}

The use of osseointegrated craniofacial implants for retention of extraoral prostheses, such as ears, offers excellent support and retentive abilities, and improves patient's appearance and quality of life. The use of implants can eliminate or minimize the need for adhesive and allows for proper orientation and seating of auricular prosthesis by the patient [1-6]. The good quality of retention gained by the implants makes it possible to fabricate large prosthesis and provide the patient in the same time with good aesthetics which he will accept. Many retention options have been used to retain ear prosthesis such as bar/clip attachments, magnets, composite bar and magnets and ball and socket attachments [7-10].

However, a satisfactory outcome may be only achieved by careful planning in terms of the number and position and orientation of the implants and the proper connection of the auricular prosthesis to implant retaining structure with cast, machined bar or attachments. The implants must be positioned within the confines of the proposed facial prosthesis. In cases of bilateral missing ears, a complete sculpture of both the definitive ears is fabricated in wax before the surgery and used to fabricate a surgical template. In case of losing only one ear, a replica of the existing ear is duplicated in wax and used to fabricate the surgical template. This template is used to guide at the surgery to ensure the proper position and angulations of the implants.

The location and orientation of craniofacial implants is critical to achieve an optimal prosthetic result. Preimplant treatment planning is essential to coordinate the patient's surgical and prosthetic management. A full-contour surgical template assists the surgeon in determining the required location of the implants relative to the anticipated prosthesis orientation [11]. However, it takes time for fabrication of a wax sculpture and consequently increase the planning time.

Assessment by CT of the structure and thickness of the bone, and mastoid process and its air cell system that is available for implantation is therefore most important in preoperative planning. Also, the position of the sigmoid sinus and the level of the middle cranial fossa have to be determined to avoid penetration [12].

Many techniques have been advocated for the orientation of the surgical template. The surgical template was first report in 1997 by Reisberg and Habakuk [11] who described a positioner at the time of surgery that guide the placement of the implants to achieve optimum results. Russell [12] made an accurate duplicate of the diagnostic wax ear for the surgical template fabrication. He used indexes on the wax contour of the ear to easily identify its orientation in relation to the patient's anatomic landmarks, namely, external auditory canal, posterior superior and inferior borders of the remaining tragus (if present). The full contour wax is duplicated to acrylic surgical template. One technique used occlusal maxillary splint connected with extraoral bar to the acrylic ear prosthesis for orientation [13]. Many others used sophisticated imaging techniques like CT, Digital Volume Topography, and laser scanning and rapid prototyping and free form modelling system which uses MRI digitizer that make image capturing of the patient healthy ear, image processing, and ear prosthesis making [14]. Another imaging technique is used to fabricate stereolithographic models and customized drill guides [15].

The objective of this paper is to describe the proposed technique for orientation of a bone anchored auricular prostheses through the presentation of two clinical cases.

\section{CLINICAL CASES \\ Patient number 1}

A 38 years old black male from Nigeria suffered from an injury (caused by fallen glass that cut his right ear), was referred for prosthetic rehabilitation. The patient presented with some scar tissue as a result of wound closure surgery (keloid). These tissues were firm, rubbery lesions and shiny, fibrous nodules, and dark brown in color. It extended about $6 \mathrm{~cm}$ long and $3 \mathrm{~cm}$ wide from the mastoid area forward and around the original wound. No localized inflammation was noticed (Figures 1 - 3). A CT, frontal and lateral cephalometric radiographs were taken to evaluate the mastoid process and the adequacy of bone height and width in the anticipated implantation site. Twostage surgical procedure, similar to the procedures used intraorally, was employed. Surgical placement

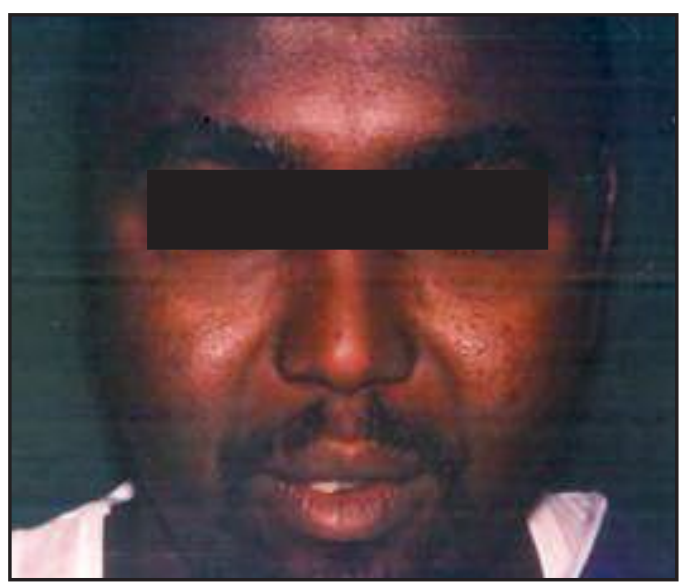

Figure 1. The patient number 1 with missing right ear. 


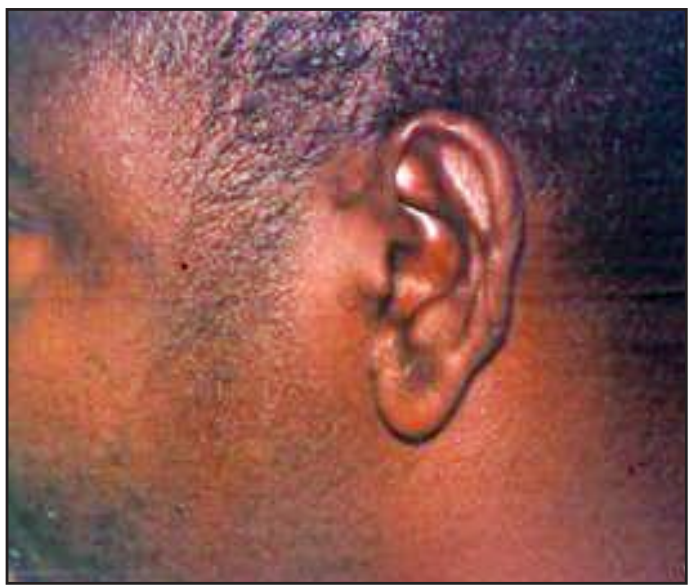

Figure 2. The left intact ear.

was conducted under general anaesthesia after admission of the patient in a hospital session for overnight.

Drawing and measurement of distances were made on a radiographic film before reflection of the flap. The technique proposed in this clinical report uses a presterilized (in Cidex) transparent radiographic film or a celluloid paper to draw the intact ear with its external and internal anatomy precisely (Richardo-Allen Surgical Marking Pen, USA). Then mark indexes on the drawing and measure distances from them to fixed anatomical features of the patient in different planes like the canthus of the eye and the corner of the mouth. Then by flipping the drawing to the opposite side, a mirror image of the ear is obtained. This image represents an ear that is the same size and contour of the intact ear. It should be positioned and related to the anatomical features in the defect side of the patient by orienting the drawing and the indexes on it to the same distances and angulations taken from the intact side and marked on the surgical site (Figures 4 - 7). A trough (groove) is made in the film from 9 o'clock to 11 o'clock position along the antihelix

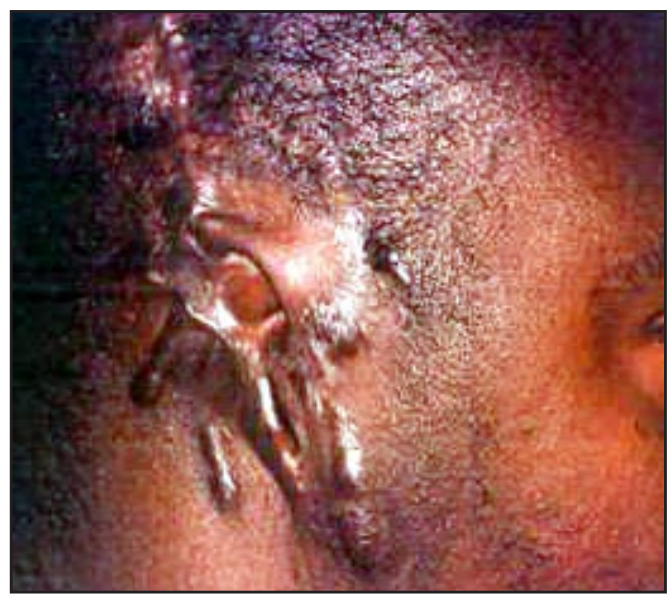

Figure 3. Scar tissue at the defect side from previous closure of the wound with many lumps.

area for the right ear and from 1 o'clock to 3 o'clock position for the left ear. This film is used as a surgical template to place the implants in their anticipated correct position in relation to anatomic features of the face and to the final ear prosthesis (Figures 8, 9) [1]. A full thickness flap was reflected by a plastic surgeon and potential implant sites were evaluated with the help of the surgical template made from the drawn intact ear on the radiographic film. A series of drills from ANKYLOS EO Extraoral Implant System by Degussa Dental (A DENTSPLY International Company Degussa Dental GmbH, Germany) were used with maximum r.p.m. of 800 with copious irrigation with saline to avoid the risk of localized overheating of the bone. The drilling was carried out according to the manufacturer's instructions to prepare the osteotomy sites for insertion of craniofacial implants.

Three $6 \mathrm{~mm}$ length implants were inserted very slowly with the aid of ratchet insert for implant and was guided to position by an open-end wrench till its final position.

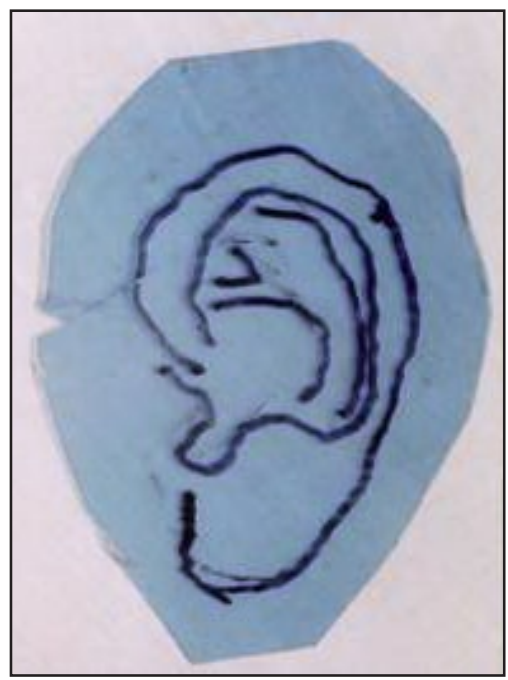

Figure 4. Drawing of the intact ear on transparent celluloid paper.

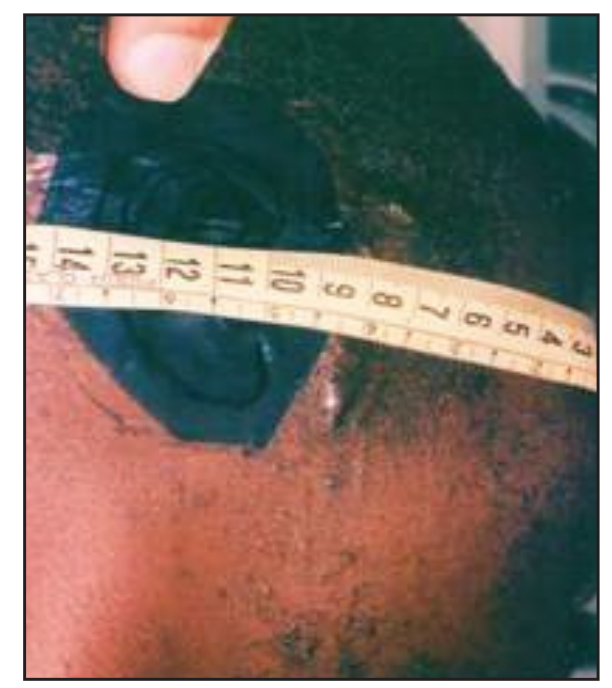

Figure 5. Measuring distances to the canthus of the eye.

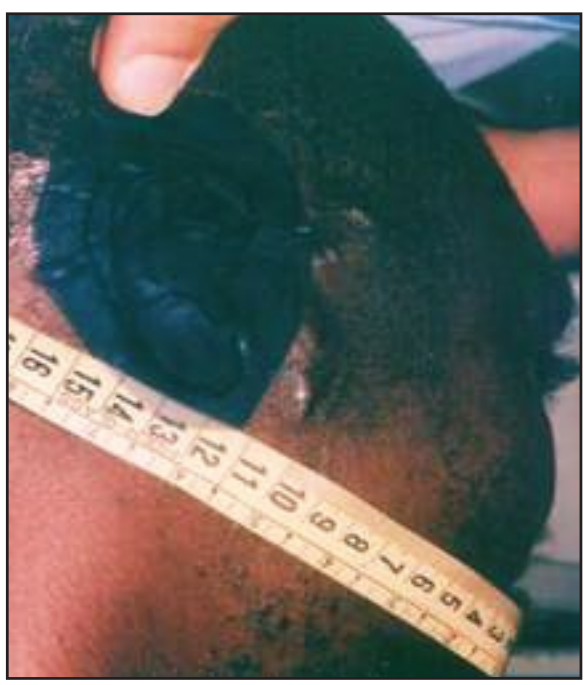

Figure 6. Measuring distance to the corner of the mouth. 


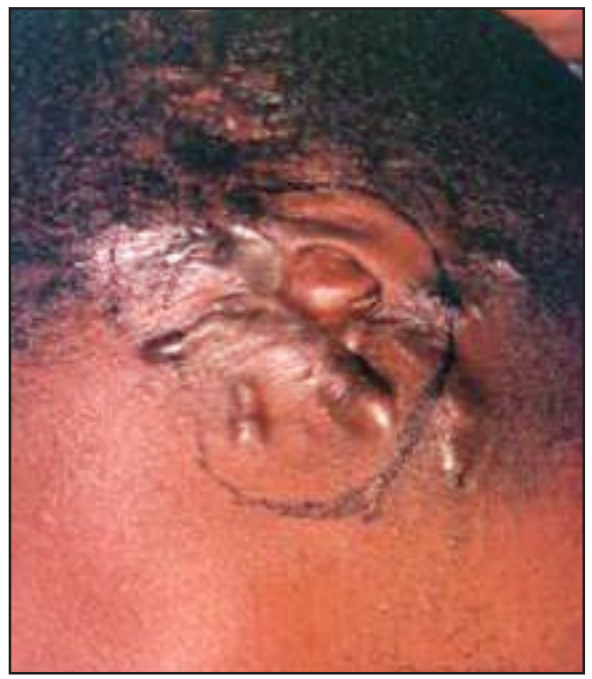

Figure 7. Drawing the shape of the intact ear on the defect side in the same orientation.

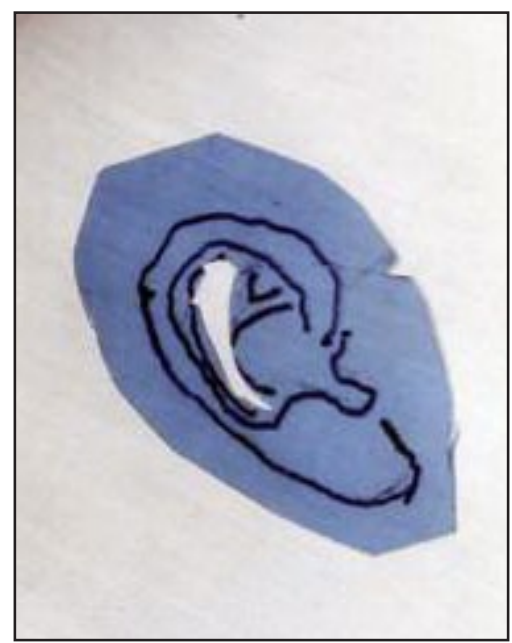

Figure 8. Making a groove for placement of the implants within the antihelix of the ear.

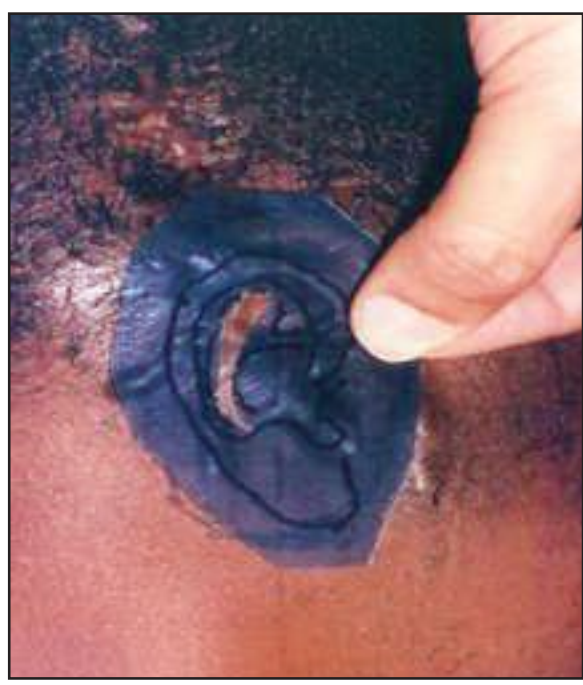

Figure 9. Orientation of the surgical template with the groove over the surgical site.
Primary stability of the implant is indispensable prerequisite for successful osseointegration. A transmucosal healing sulcus former was inserted immediately following placement of the implants. Thinning of the skin layer and removal of any tissue remnants was carried out to avoid postoperative inflammation and to allow protrusion of the transmucosal healing sulcus former. The operation site was sutured in 3 layers with stress free sutures. A mastoid pressure dressing was placed and maintained for 48 hours. The non-resorbable sutures were removed 7 days later. A healing period of 3 - 4 months was allowed before the prosthetic procedures started (Figures $10-12$ ).

\section{Patient number 2}

A 25 year old male presented with aplasia of the left ear. He has gone through series of plastic surgeries to reconstruct the missing ear with a Teflon ring that is covered by grafted soft tissue. All of them failed. Removal of the Teflon ring was carried out during the surgery and all the damaged graft soft tissue related to it. This lead to a wide area of scar tissue that extended beyond the mastoid bone. The same procedures were carried out. The orientation technique was done on the intact side and transferred to the defect side in the surgical room. This simplified surgical template was used to insert 3 craniofacial implants in the mastoid bone area within the confines of the antihelix area of the definitive auricular prosthesis (Figures 13 - 17).

\section{DISCUSSION}

The design of the surgical craniofacial implant stent must account for several treatment conditions, including position of the implant, the tissue present, ease, fast fabrication and the anticipated prosthesis.

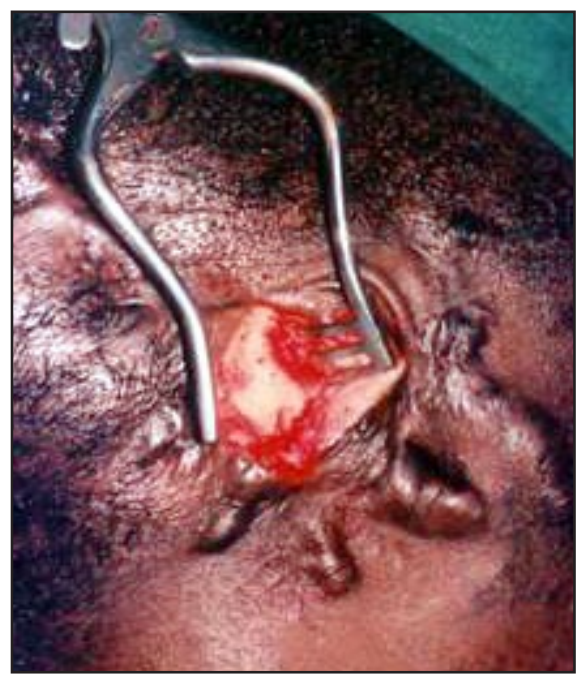

Figure 10. Full thickness flap.

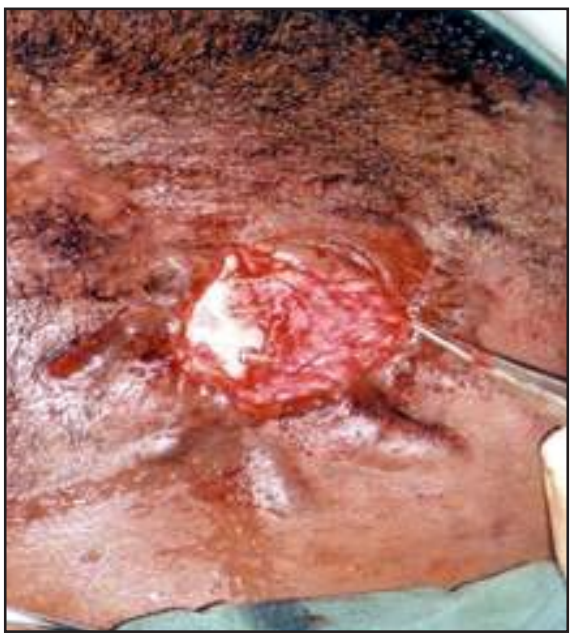

Figure 11. Three implants in place with their cover screws.

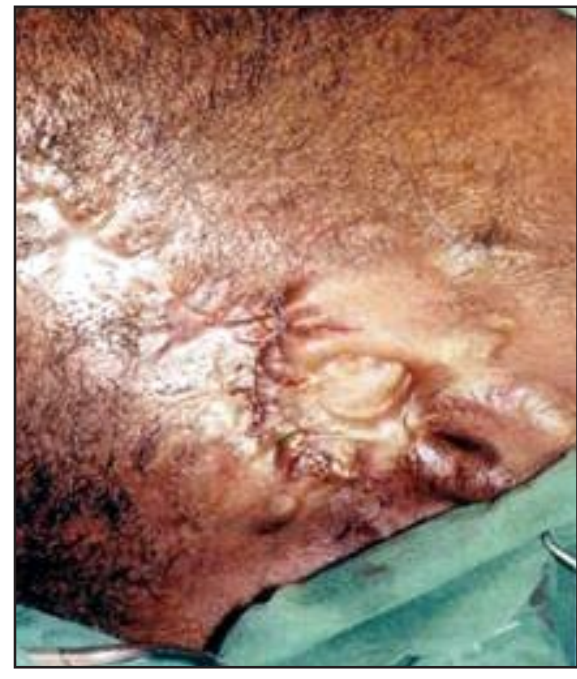

Figure 12. Final closure of the surgical site. 

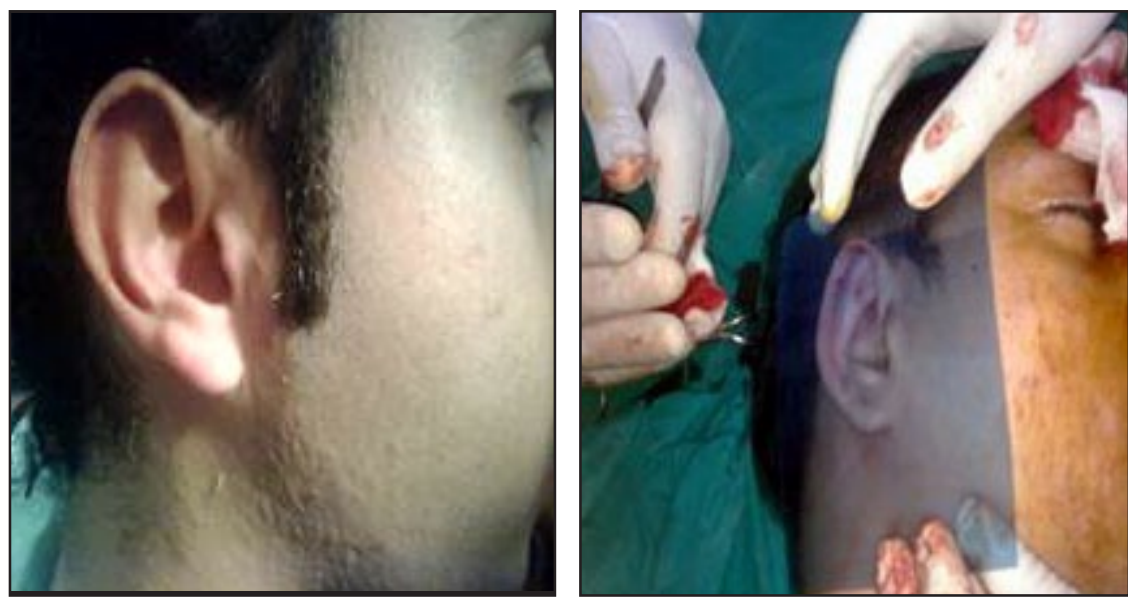

Figure 13. Normal side of patient Figure 14. Positioning the radiographic film number 2 . on the normal side.

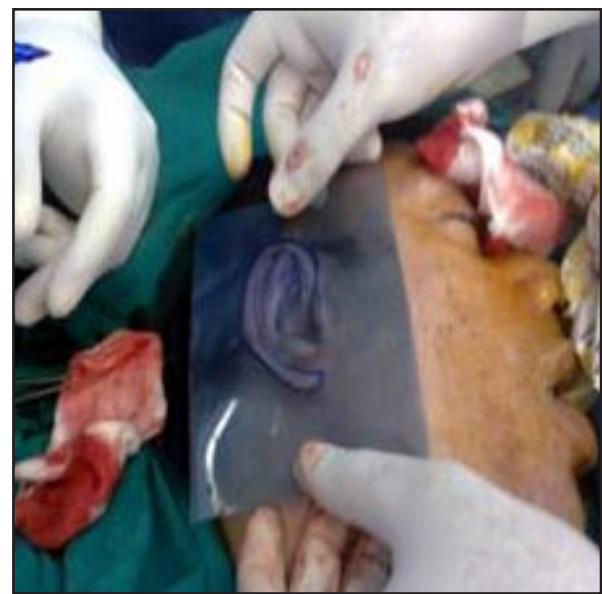

Figure 15. Drawing the ear on radiographic film on the normal side.

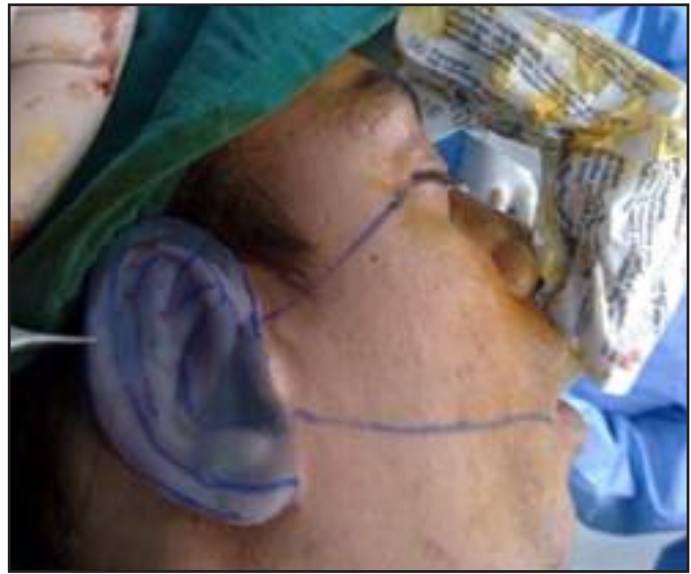

Figure 16. Orientation of the normal ear to the canthus of the eye and corner of the mouth.

The technique proposed in this clinical study includes drawing of the intact ear on a transparent celluloid paper or radiographic film and flips it to the opposite side and relates it to fixed anatomical features on the face of the patient. The drawing, by this way provides a simple and easy way to duplicate and transfer the exact size and position of the intact ear to the defect side and provide a simple surgical template that orients the implants to the confines of the definitive prosthesis and can be easily disinfected and used in the operating room. This template enabled the surgeon to work while the patient is lying in his side. This technique, avoid also, early wax sculpture of the ear that takes time and increase the planning time. This technique avoided also, preservation of this wax sculpture for long periods of time (3 - 6 months) until complete osseointegration is evident and avoided sophisticated imaging and fabrication procedures [11-15]. It also, safe because it eliminated the need for exposing the patient to varying degrees of radiation according to the imaging system used [14]. These imaging techniques for fabrication of surgical guide are very costly, require sophisticated technologies,

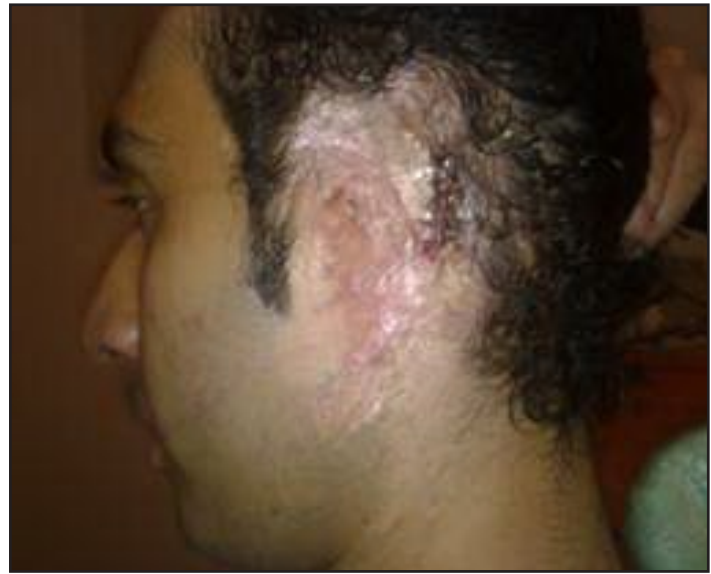

Figure 17. The 3 implants after positioned in correct anatomical site.

may not be able to reproduce all the anatomic features, and works only with the presence of intact ear in the other side [14]. Some of these techniques are very difficult to apply in the operating room [13].

The patients presented in this study suffered from different situations. The first patient has a severe prominent scar tissue in the missing ear site which could be due to formation of keloid tissue. The frequency of occurrence is 15 times higher in highly pigmented people. Persons of African descent are at increased risk of keloid occurrences [17]. The keloid tissue with its lumps in the missing ear site may sometimes interfere with proper positioning of the auricular surgical stents and wax sculpture. The technique proposed in this study used flexible radiographic film as the auricular surgical stent that allowed drawing on the missing ear site without interference with theses lumps. The other patient also, ended up with a wide area of scar tissue after removal of the failed Teflon ring that was placed as an attempt from a plastic surgeon to reconstruct a complete missing ear due to strong foreign body reaction. This wide area of scar tissue could affect the surgeon's 
ability to position the craniofacial implant properly. This problem was solved by using the proposed technique in which strict adherence to the distances and angulations measured from the intact side were applied. Using the flexibility of the film, the surgeon was able to position the craniofacial implants within the confines of the antihelix of the ear despite the variation in the surface anatomy. The proposed technique could be indicated in all patients with aplasia, injury and resection of one ear. However, there are some limitations of this technique in a situation where patient has a congenital facial asymmetry that require that the surgeon correct the distances measured from the normal side to fit with those of defect side and do not violate the anatomy. It does not allow three-dimensional visualization of wax pattern as in the sculpture technique. It is also, difficult to apply this technique in cases of bilateral missing ears. However, a wax auricular prosthesis that is suitable to the patient could be fabricated first and positioned on the face and the proposed technique could be applied as if it a natural ear.

\section{CONCLUSIONS}

This technique provides a simple, safe, inexpensive and time saving yet, effective and accurate surgical template that orients the craniofacial implants to the confines of the definitive auricular prosthesis. It works easily in cases of severe scars, lumps and granulation tissues. The proposed technique could be indicated in all patients with aplasia, injury and resection of one ear.

\section{ACKNOWLEDGMENTS AND DISCLOSURE STATEMENTS}

The authors report no conflicts of interest related to this study.

\section{REFERENCES}

1. Beumer J, Curtis TA, Marunick MT. Maxillofacial Rehabilitation. In: Prosthodontic and Surgical Considerations. Ishiyaku Euro America:St.Louis; 1996. p. 437.

2. Roumanas ED, Chang TL, Beumer J. Use of osseointegrated implants in the restoration of head and neck defects. J Calif Dent Assoc. 2006 Sep;34(9):711-8. [Medline: 17022295]

3. Abu-Serriah MM, McGowan DA, Moos KF, Bagg J. Extra-oral endosseous craniofacial implants: current status and future developments. Int J Oral Maxillofac Surg. 2003 Oct;32(5):452-8. Review. [Medline: 14759101]

4. Visser A, Raghoebar GM, van Oort RP, Vissink A. Fate of implant-retained craniofacial prostheses: life span and aftercare. Int J Oral Maxillofac Implants. 2008 Jan-Feb;23(1):89-98. [Medline: 18416416]

5. Wright RF, Zemnick C, Wazen JJ, Asher E. Osseointegrated implants and auricular defects: a case series study. J Prosthodont. 2008 Aug;17(6):468-75. Epub 2008 Jun 9. [Medline: 18544137] [doi: 10.1111/j.1532-849X.2008.00309.x]

6. Karayazgan B, Gunay Y, Atay A, Noyun F. Facial defects restored with extraoral implant-supported prostheses. J Craniofac Surg. 2007 Sep;18(5):1086-90. [Medline: 17912089] [doi: 10.1097/scs.0b013e31815727eb]

7. Chung RW, Siu AS, Chu FC, Chow TW. Magnet-retained auricular prosthesis with an implant-supported composite bar: a clinical report. J Prosthet Dent. 2003 May;89(5):446-9. [Medline: 12806320] [doi: 10.1016/S0022-3913(03)00124-0]

8. Voigt A, Christ S, Klein M. Experimental analysis of retention forces of different magnetic devices for bone-anchored auricular facial prostheses. Int J Oral Maxillofac Surg. 2008 Jul;37(7):664-8. Epub 2008 Apr 28. [Medline: 18440779] [doi: 10.1016/j.ijom.2008.02.010]

9. de Sousa AA, Mattos BS. Magnetic retention and bar-clip attachment for implant-retained auricular prostheses: a comparative analysis. Int J Prosthodont. 2008 May-Jun;21(3):233-6. [Medline: 18548962]

10. Hegde C, Krishma DP, Shukla P, Shetty M. Rehabilitation of auricular defects utilizing single implant and tissue support. J Indian Prosthodontic Society 2008;8(2):105-107. [doi: 10.4103/0972-4052.43613]

11. Reisberg DJ, Habakuk SW. Use of a surgical positioner for bone-anchored facial prostheses. Int J Oral Maxillofac Implants. 1997 May-Jun;12(3):376-9. [Medline: 9197103]

12. Wang R. Preoperative auricular wax pattern duplication for surgical template fabrication. J Prosthet Dent. 1999 May;81(5):634-7. Medline: 10220672. [doi: 10.1016/S0022-3913(99)70222-2]

13. Girod SC, Rohlfing T, Maurer CR Jr. Image-guided surgical navigation in implant-based auricular reconstruction. J Oral Maxillofac Surg. 2008 Jun;66(6):1302-6. [Medline: 18486803] [doi: 10.1016/j.joms.2007.06.636]

14. Alfano SG, Robinson RF, Webber CM, Erickson KK. Fabrication of a craniofacial implant surgical and treatment planning guide. J Prosthet Dent. 2005 Jan;93(1):91-4. [Medline: 15624004] [doi: 10.1016/j.prosdent.2004.07.012]

15. Haung $X$, Ye M, Zhang W, Wang C, Jiao T: Fabricating auricular prostheses based on rapid prototyping and the FreeForm modelling system. Int J Adv Manuf Technol. 2004 Dec;24(11):873-8. [doi: 10.1007/s00170-003-1814-8] 
16. Verielink L. CT-based planning for extra-oral implant placement using customized drill guides. Materials Dental 2008. URL:http://old.materialise.com/materialise/view/fr/382317-Extra-oral+Implant+Placement.html?cat=115089

17. Meenakshi J, Jayaraman V, Ramakrishnan KM, Babu M. Keloids and hypertrophic scars: a review. Indian J Plast Surg. 2005;38(2):175-9. [doi: 10.4103/0970-0358.19796]

\section{To cite this article:}

El Charkawi HG, El Sharkawi AG. A Simplified Technique for Orientation of a Bone Anchored Auricular Prostheses: a Clinical Report.

J Oral Maxillofac Res 2012;3(3):e6

URL: http://www.ejomr.org/JOMR/archives/2012/3/e6/v3n3e6ht.pdf

doi: $10.5037 /$ jomr.2012.3306

Copyright (C) El Charkawi HG, El Sharkawi AG. Accepted for publication in the JOURNAL OF ORAL \& MAXILLOFACIAL RESEARCH (http://www.ejomr.org), 7 August 2012.

This is an open-access article, first published in the JOURNAL OF ORAL \& MAXILLOFACIAL RESEARCH, distributed under the terms of the Creative Commons Attribution-Noncommercial-No Derivative Works 3.0 Unported License, which permits unrestricted non-commercial use, distribution, and reproduction in any medium, provided the original work and is properly cited. The copyright, license information and link to the original publication on (http://www.ejomr.org) must be included. 